\title{
(2) OPEN ACCESS \\ Tumour immune microenvironment biomarkers predicting cytotoxic chemotherapy efficacy in colorectal cancer
}

\author{
Kate Wilkinson 지 1,2 Weng $\mathrm{Ng}^{1,2}$ Tara Laurine Roberts, ${ }^{2,3}$ Therese M Becker, ${ }^{2,3}$ \\ Stephanie Hui-Su Lim, ${ }^{2,3,4}$ Wei Chua, ${ }^{1,2,3}$ Cheok Soon Lee ${ }^{2,3,5}$
}

1 Liverpool Cancer Therapy Centre, Liverpool Hospital, Liverpool, New South Wales, Australia

${ }^{2}$ School of Medicine, Western Sydney University, Liverpool, New South Wales, Australia ${ }^{3}$ Ingham Institute for Applied Medical Research, Liverpool, New South Wales, Australia ${ }^{4}$ Macarthur Cancer Therapy Centre, Campbelltown Hospital, Campbelltown, New South Wales, Australia

${ }^{5}$ Department of Anatomical Pathology, Liverpool Hospital, Liverpool, New South Wales, Australia

\section{Correspondence to}

Dr Kate Wilkinson, Liverpool Cancer Therapy Centre, Liverpool, NSW 2170, Australia; kate.wilkinson1@health.nsw. gov.au

Received 1 December 2020 Accepted 22 December 2020 Published Online First 22 March 2021

\begin{abstract}
The role of the local tumour and stromal immune landscape is increasingly recognised to be important in cancer development, progression and response to therapy. The composition, function, spatial orientation and gene expression profile of the infiltrate of the innate and adaptive immune system at the tumour and surrounding tissue has an established prognostic role in colorectal cancer (CRC). Multiple studies have confirmed that a tumour immune microenvironment (TIME) reflective of a type 1 adaptive immune response is associated with improved prognosis. There have been significant efforts to evolve these observations into validated, histopathology-based prognostic biomarkers, such as the Immunoscore. However, the clinical need lies much more in the development of predictive, not prognostic, biomarkers which have the potential to improve patient outcomes. This is particularly pertinent to help guide cytotoxic chemotherapy use in CRC, which remains the standard of care. Cytotoxic chemotherapy has recognised immunomodulatory activity distinct from its antimitotic effects, including mechanisms such as immunogenic cell death (ICD) and induction/inhibition of key immune players. Response to chemotherapy may differ with regard to molecular subtype of CRC, which are strongly associated with immune phenotypes. Thus, immune markers are potentially useful, though under-reported, predictive biomarkers. In this review, we discuss the impact of the TIME on response to cytotoxic chemotherapy in $\mathrm{CRC}$, with a focus on baseline immune markers, and associated genomic and transcriptomic signatures.
\end{abstract}

\section{INTRODUCTION}

The tumour immune microenvironment (TIME) has an important role in mediating cytotoxic drug response and resistance, as illustrated by the differences in efficacy between in vitro, ectopic tumour mouse models and humans. ${ }^{1}$ The TIME is extremely complex in colorectal cancer (CRC), reflecting genomic, host immunity and environmental (including microbiome) diversity. ${ }^{2}$ The immune visibility and susceptibility of CRCs can vary widely, and explain differential prognosis. The baseline TIME may facilitate immune evasion through low antigenicity, paucity of immune effectors or immunosuppressive mechanisms, which may contribute to primary resistance to chemotherapy. However, it is hypothesised that immunostimulatory chemotherapy may overcome these deficits specifically to improve prognosis, or conversely be redundant in an optimally infiltrated tumour. There is a significant clinical need to identify biomarkers of response to the standard cytotoxics used in CRC-the antimetabolites (5-fluorouracil (5-FU) and capecitabine), platinum derivatives (oxaliplatin) and topoisomerase inhibitors (irinotecan). This review will summarise the key literature and studies that focus on baseline, pretreatment TIME histopathological markers as potential predictive and prognostic biomarkers in patients with CRC receiving cytotoxic chemotherapy. Biomarkers relevant to radiotherapy and novel immunotherapies are outside the scope of this review.

\section{TIME ASSESSMENT IN CRC}

The TIME is composed of various infiltrating cells of the innate and adaptive immune system and their associated mediators. Immune cells can be identified in the core of the tumour $\left({ }_{\mathrm{CT}}\right)$, both in intraepithelial cancer cell nests, or the tumour stroma $\left({ }_{\mathrm{CS}}\right)$; at the invasive margin $\left({ }_{\mathrm{IM}}\right)$, and in organised tertiary lymphoid structures $\left({ }_{\mathrm{TLS}}\right)$ distant from the tumour ${ }^{3}$ (figure 1 ). This nomenclature will be used in the review to identify biomarker location where identified in respective papers. The cell type, location, density and functional orientation are all relevant for prognostication. Peritumoural infiltrates can be assessed on H\&E-stained slides, using semiquantitative validated scoring systems including the Klintrup-Mäkinen (KM) grade ${ }^{4}$ and the Jass score. ${ }^{5}$ Multiplex immunohistochemical (IHC) techniques in clinically annotated tumour slides, to identify specific immune cells based on surface markers, is currently one of the key assessments of the TIME. Whole slides can be assessed, or tissue microarray techniques used to allow high throughput of samples. Cell density estimation can be performed manually, or assessed through digital image analysis ${ }^{6}$ and machine learning algorithms to allow objective quantification, although scoring methodology varies widely. Advances in RNA sequencing, proteomics and single-cell technologies are also increasingly used to assess the TIME. Techniques such as CIBERSOrT ${ }^{7}$ and MCPcounter $^{8}$ can estimate the abundance of immune infiltrate in the tumour using the gene expression data from bulk tissues. Mass cytometry provides data at the individual cell level, and single-cell RNA sequencing allows profiling and classification of individual immune cells. ${ }^{9}$ Tumour heterogeneity 


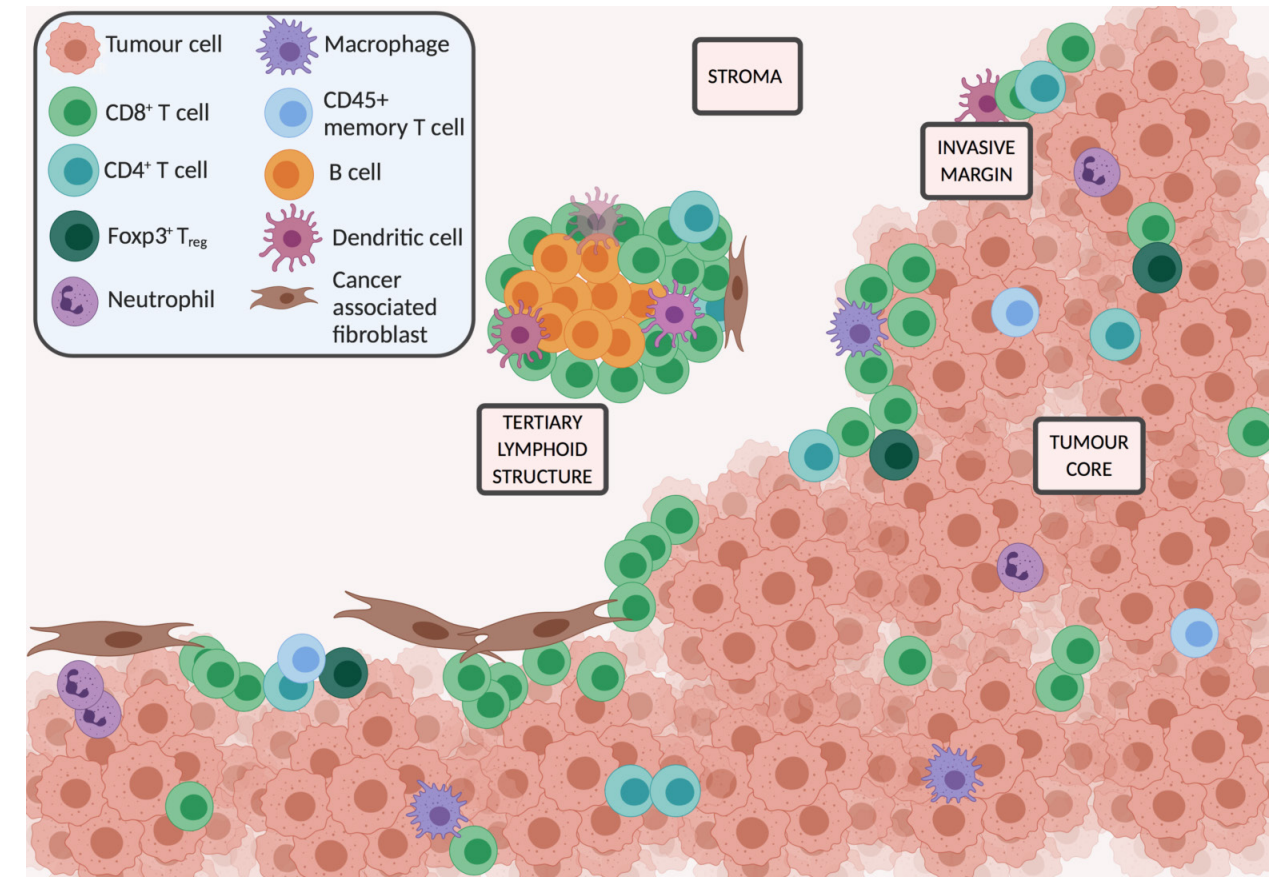

Figure 1 Key cells and locations in the tumour immune microenvironment.

and sampling issues add complexity to the use of biopsy-driven TIME biomarkers. Key cell types analysed using IHC techniques are listed in table 1, in addition to a summary of their known prognostic and predictive associations.

\section{IMMUNOMODULATORY MECHANISM OF ACTION OF CYTOTOXIC CHEMOTHERAPY}

Many chemotherapeutic agents, including oxaliplatin, fluoropyrimidines and irinotecan, have local and systemic immunomodulatory effects beyond their cytostatic mechanisms. ${ }^{10-12}$ Preclinical models demonstrate that chemotherapy can augment immune responses directly by activation of immune effector cells

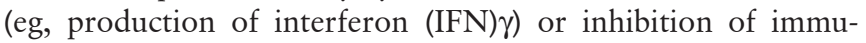
nosuppressive factors (such as circulating regulatory $\mathrm{T}$ cells $\left.\left(\mathrm{T}_{\text {regg }}\right)^{13}\right)$, or act on tumours directly to increase antigenicity, ${ }^{14} 15$ immunogenicity ${ }^{15}$ or susceptibility to immune attack through other mechanisms. ${ }^{12}{ }^{16} \mathrm{~A}$ small repertoire of chemotherapeutics, including oxaliplatin, can generate a specific mechanism of cell death, termed 'immunogenic cell death' (ICD), whereby release of specific danger signals from dying tumour cells stimulates a dendritic cell (DC)-mediated, cytotoxic T-helper 1 $\left(T_{h} 1\right)$ response to eradicate residual tumour cells. ${ }^{17-19}$ Platinum cytotoxics can cause DC maturation, ${ }^{14}$ downregulate immune checkpoints and thus increase $\mathrm{CD} 8^{+} \mathrm{T}$ cell activation. ${ }^{20}{ }^{21} \mathrm{In}$ vivo, fluoropyrimidines selectively deplete immunosuppressive myeloid-derived suppressor cells (MDSCs), ${ }^{22}$ although have also been associated with a pro-tumour $\mathrm{T}_{h} 17$ response. ${ }^{23}{ }^{24}$ The immunogenicity of irinotecan is less certain, although in vivo work has reported influence on $\mathrm{T}_{\text {reg }}$ and MDSC infiltration, ${ }^{25}$ and upregulation of tumour PD-L1. ${ }^{26}$ For clinical correlation, patients receiving neoadjuvant (preoperative) 5-FU/oxaliplatin show increased infiltration of $\mathrm{CD}^{+},{ }^{27}{ }^{28}$ natural killer (NK) and $\mathrm{CD} 8{ }^{+}$cells $^{29}$ in resected liver metastases compared with patients undergoing upfront surgery. Neoadjuvant fluoropyrimidines increase the density of $\mathrm{CD} 3^{+}{ }_{\mathrm{CS}}$ and $\mathrm{CD} 8^{+}{ }_{\mathrm{CS}}$ cells in patients with resected rectal cancer compared with pretreatment biopsies. ${ }^{30} 31$
TIME BIOMARKERS

\section{Inflammatory infiltrate}

Increased tumour inflammatory infiltrate is strongly associated with improved survival, ${ }^{32}$ although most studies do not specify survival by subgroups based on chemotherapy utilisation. For those studies that do, an increased infiltrate seems to confer a positive prognostic advantage in patients receiving chemotherapy, mirroring the trend in the untreated population. A higher KM grade (more florid infiltrate at invasive margin) is associated with improved overall survival (OS) in patients receiving adjuvant chemotherapy (unspecified regimes) ${ }^{33} 34$ and FOLFOX (infusional 5-FU and oxaliplatin) chemotherapy. ${ }^{35}{ }^{36}$ Tumourinfiltrating lymphocyte (TIL) density ${ }_{\mathrm{CT} \text { and } \mathrm{IM}}$ was not prognostic in stage II/III patients receiving adjuvant 5 -FU plus oxaliplatin regimes $^{37}$; however, increased primary TIL density was associated with improved response rates $(79 \%$ vs $48 \%, \mathrm{p}=0.025)$ to doublet chemotherapy (oxaliplatin or irinotecan based) in patients with metastatic disease. ${ }^{38}$ This is notable as the primary tumour TIME appeared to impact on response rates at distant metastatic sites. Morris et $a l^{39}$ reported a significant survival benefit with adjuvant 5 -FU chemotherapy versus observation in stage III patients $(\mathrm{n}=1156)$ with peritumoural TILs present (HR $0.22, \mathrm{p}<0.001$ ) which was not evident in patients with absent TILs (HR 0.84, $p=0.29$ ). This suggests a possible predictive role, with 5 -FU being more efficacious in patients with pre-existing immune recognition; however, non-standardised methods were used to identify TILs in this study which may impact validity.

\section{$\mathrm{CD}^{+} / \mathrm{CD}^{+} \mathrm{T}$ cells}

The predominant infiltrating immune cells in CRC are T lymphocytes, identified by the generic $\mathrm{CD}^{+}$surface marker. Cytotoxic $\mathrm{CD}^{+} \mathrm{T}$ lymphocytes recognise tumour antigen presented by MHC class I molecules, thus providing the key antitumour immune response. High density of $\mathrm{CD} 3^{+}$and $\mathrm{CD} 8^{+} \mathrm{T}$ cells in the core tumour and invasive margin are well established as a positive prognostic marker in the majority of CRC studies. ${ }^{32}$ 
Table 1 Primary tumour prognostic and predictive IHC-based TIME biomarkers in patients receiving chemotherapy

\begin{tabular}{|c|c|c|c|c|}
\hline Immune biomarker & Location & $\begin{array}{l}\text { Prognostic role in early stage patients receiving } \\
\text { adjuvant chemotherapy (regime) }\end{array}$ & $\begin{array}{l}\text { Prognostic role in stage IV patients receiving } \\
\text { palliative chemotherapy (regime) }\end{array}$ & $\begin{array}{l}\text { Predictive role or differential biomarker } \\
\text { prognostic role by treatment group }\end{array}$ \\
\hline \multicolumn{5}{|l|}{ Specific immune cell } \\
\hline \multirow[t]{2}{*}{$\mathrm{CD}^{+}$} & $\mathrm{CT}$ & $\begin{array}{l}\text { Most studies - î density=positive prognostic assoc } \\
\text { Improved OS } 36404243 \text { and DFS } \\
\text { Improved DFS (FOLFOX) } \\
\text { I4 } 45 \text {-FU) } \\
\text { Few studies - no association } \\
\text { OS (unspecified regimes) } \\
\text { (5-FU+/-bevacizumab) }^{47} \text { and DFS }\end{array}$ & $\begin{array}{l}\text { îdensity=positive prognostic assoc } \\
\text { Improved OS (unspecified regimes) }\end{array}$ & $\begin{array}{l}\text { Possible negative predictive role (adjuvant } \\
\text { chemotherapy unspecified) } \\
\text { î density (vs low density)=improved OS in } \\
\text { observation group (not chemotherapy group) }\end{array}$ \\
\hline & $\mathrm{IM}$ & $\begin{array}{l}\text { î density=mixed findings } \\
\quad \text { No association } \mathrm{DFS}^{48} \text { or } \mathrm{OS}^{40}(5-\mathrm{FU}) \\
\quad \text { Improved DFS } \\
\end{array}$ & $\begin{array}{l}\text { îdensity=positive prognostic assoc } \\
\text { Improved OS (unspecified regimes) }\end{array}$ & \\
\hline \multirow[t]{2}{*}{$\mathrm{CD}^{+}$} & $\mathrm{CT}(\mathrm{CS})$ & 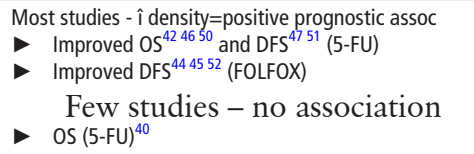 & $\begin{array}{l}\text { î density=mixed findings } \\
\quad \text { Improved OS (oxal/irinotecan }+5-\text { FU) })^{54} \\
\quad \text { No assoc OS (unspecified regime }{ }^{55} \text { and FOLFOX) }{ }^{56}\end{array}$ & $\begin{array}{l}\text { No predictive role (adjuvant 5-FU) } \\
\text { îdensity=improved OS in patients treated with } \\
\text { and without adjuvant chemotherapy }{ }^{46}\end{array}$ \\
\hline & IM & $\begin{array}{l}\text { Most studies - î density=positive prognostic assoc } \\
\text { Improved OS }(5-\mathrm{FU})^{53} \\
\left.\text { Improved DFS (FOLFOX, }{ }^{45} \text { CAPOX) }\right)^{52} \\
\text { Few studies - no association } \\
\text { OS }\left(5-\mathrm{FU}^{40}{ }^{40} \text { unspecified regime }\right)^{71}\end{array}$ & $\begin{array}{l}\text { No prognostic assoc } \\
\text { OS (unspecified regime) }\end{array}$ & $\begin{array}{l}\text { Possible positive predictive role (adjuvant } 5 \text {-FU) } \\
\text { î density (vs low density)=OS benefit } \\
\text { greater for patients treated with adjuvant } \\
\text { chemotherapy>observation }\end{array}$ \\
\hline \multirow[t]{2}{*}{$\mathrm{CD}^{+}$} & $\mathrm{CT}$ & & $\begin{array}{l}\text { Î density=mixed findings } \\
\quad \text { Improved OS (unspecified regimes) } \\
\text { No association OS (FOLFOX) }\end{array}$ & \\
\hline & $\mathrm{IM}$ & & $\begin{array}{l}\text { î density=positive prognostic assoc } \\
\\
\quad \text { Improved OS (unspecified regimes) }^{55}\end{array}$ & \\
\hline $\begin{array}{l}\text { Immunoscore } \\
\left(\mathrm{CD}^{+} \text {and } \mathrm{CD}^{+}{ }_{\mathrm{CT}}\right. \\
\left.+{ }_{\text {IIM }}\right)\end{array}$ & $0-4$ & $\begin{array}{l}\text { High score=positive prognostic assoc } \\
\text { Improved DFS high-risk stage II (5-FU) } \\
\text { Improved DFS stage III (FOLFOX) } \\
\text { Improved OS stage III (5-FU, } \\
\text { I362 variable } \\
\text { regimes) }{ }^{64}\end{array}$ & & $\begin{array}{l}\text { Positive predictive role stage III (various adjuvant } \\
\text { regimes) } \\
\text { High IS (2-4)=DFS benefit with adjuvant } \\
\text { chemotherapy (vs low IS } 0-1 \text { - no benefit) } \\
\text { Not predictive stage II (adjuvant 5-FU) }\end{array}$ \\
\hline \multirow[t]{2}{*}{ Foxp3 $^{+}\left(\mathrm{T}_{\text {reg }}\right)$} & $\mathrm{CT}$ & $\begin{array}{l}\text { î density=mixed findings } \\
\quad \text { Improved OS (5-FU) } \\
\text { No association DFS }(5-F U)^{41} \\
\quad \text { Worse DFS/OS (unspecified regime) }\end{array}$ & $\begin{array}{l}\text { î density=mixed findings } \\
\text { Improved OS (FOLFOX, }{ }^{56} 5-\mathrm{FU}+\text { oxaliplatin or } \\
\text { irinotecan) } \\
\text { No association OS (unspecified regime) }\end{array}$ & $\begin{array}{l}\text { Mixed findings } \\
\text { Not predictive (adjuvant 5-FU) } \\
\text { Possible negative predictive role (adjuvant } \\
\text { chemotherapy unspecified) } \\
-\quad \text { i density (vs low density)=worse OS/DFS } \\
\text { in adjuvant chemotherapy group (not } \\
\text { observation group) }\end{array}$ \\
\hline & $\mathrm{IM}$ & $\begin{array}{l}\text { No prognostic association } \\
\text { DFS/OS on multivariate analysis (unspecified } \\
\text { regime) }\end{array}$ & $\begin{array}{l}\text { No prognostic association } \\
\longrightarrow \text { OS (unspecified regime) }\end{array}$ & $\begin{array}{l}\text { Possible negative predictive role (adjuvant } \\
\text { chemotherapy unspecified) } \\
\text { î density (vs low density)=improved OS in } \\
\text { observation group (not chemotherapy group) }\end{array}$ \\
\hline \multirow[t]{2}{*}{$\mathrm{CD} 6 \mathrm{~b}^{+}(\mathrm{TAN})$} & $\mathrm{CT}$ & $\begin{array}{l}\text { î density=positive prognostic association } \\
\left.\quad \text { Improved DFS/OS (5-FU, }{ }^{74} \text { unspecified regime }\right)^{70}\end{array}$ & & 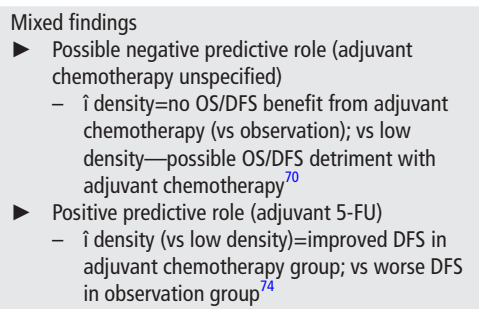 \\
\hline & $\mathrm{IM}$ & $\begin{array}{l}\text { î density=positive prognostic association } \\
\text { Improved DFS }(5-\mathrm{FU})^{75}\end{array}$ & & $\begin{array}{l}\text { Possible positive predictive role (adjuvant 5-FU) } \\
\text { î density (vs low density)=improved DFS in } \\
\text { chemotherapy group only (not observation } \\
\text { group) }^{75}\end{array}$ \\
\hline \multirow[t]{2}{*}{$\begin{array}{l}{\mathrm{CD} 68^{+}}^{+} \text {(general TAM } \\
\text { marker) }\end{array}$} & $\mathrm{CT}$ & $\begin{array}{l}\text { No prognostic assoc stage II } \\
\text { DFS/OS }(5-\mathrm{FU})^{77}\end{array}$ & $\begin{array}{l}\text { î density=negative prognostic association } \\
\text { Worse OS (unspecified regimes) }\end{array}$ & \\
\hline & $\mathrm{IM}$ & $\begin{array}{l}\text { î density=positive prognostic association } \\
\text { Improved DFS }(5-\mathrm{FU})^{75}\end{array}$ & $\begin{array}{l}\text { No prognostic association } \\
\text { OS (unspecified regime }\end{array}$ & $\begin{array}{l}\text { Possible positive predictive role (adjuvant 5-FU) } \\
\text { î density (vs low density)=improved DFS in } \\
\text { chemotherapy group (not observation group) }\end{array}$ \\
\hline $\begin{array}{l}\mathrm{CD}^{163^{+}}(\mathrm{M} 2 \\
\text { polarised TAM) }\end{array}$ & $\mathrm{CT}$ & $\begin{array}{l}\text { î density=negative prognostic association } \\
\text { Worse DFS/OS (unspecified regime) }\end{array}$ & $\begin{array}{l}\text { î density=negative prognostic association } \\
\text { Worse OS (unspecified regimes) }\end{array}$ & $\begin{array}{l}\text { Possible negative predictive role (unspecified adjuvant } \\
\text { regime) } \\
\text { îdensity (vs low density)=worse DFS in } \\
\text { chemotherapy group (not observation group) }\end{array}$ \\
\hline & $\mathrm{IM}$ & & $\begin{array}{l}\text { No prognostic association } \\
\quad \text { OS (unspecified regime) }\end{array}$ & \\
\hline $\begin{array}{l}\text { CD206+ (M2 } \\
\text { polarised TAM) }\end{array}$ & $\mathrm{CT}$ & $\begin{array}{l}\text { î density=negative prognostic association } \\
\text { Worse DFS/OS }(5-\mathrm{FU})^{77}\end{array}$ & & $\begin{array}{l}\text { Possible positive predictive role (adjuvant } 5 \text {-FU) } \\
\text { î ratio } C D 206^{+}: C D 68^{+}=\text {improved DFS with } \\
\text { adjuvant chemotherapy (vs low ratio-no } \\
\text { benefit) }\end{array}$ \\
\hline $\begin{array}{l}\mathrm{CD} 45 \mathrm{RO}^{+} \text {(memory } \\
\mathrm{T} \text { cell) }\end{array}$ & $\mathrm{CT}$ & $\begin{array}{l}\text { î density=positive prognostic association } \\
\quad \text { Improved OS }(5-\mathrm{FU})^{42} 43\end{array}$ & $\begin{array}{l}\text { î density=positive prognostic association } \\
\text { Improved OS (oxal//irinotecan+5-FU) }\end{array}$ & \\
\hline
\end{tabular}




\begin{tabular}{|c|c|c|c|c|}
\hline Immune biomarker & Location & $\begin{array}{l}\text { Prognostic role in early stage patients receiving } \\
\text { adjuvant chemotherapy (regime) }\end{array}$ & $\begin{array}{l}\text { Prognostic role in stage IV patients receiving } \\
\text { palliative chemotherapy (regime) }\end{array}$ & $\begin{array}{l}\text { Predictive role or differential biomarker } \\
\text { prognostic role by treatment group }\end{array}$ \\
\hline & IM & $\begin{array}{l}\text { î density=positive prognostic association } \\
\square \quad \text { Improved OS (unspecified regime) }\end{array}$ & & $\begin{array}{l}\text { No predictive role (adjuvant chemotherapy } \\
\text { unspecified) } \\
\text { îdensity=improved OS in patients treated with } \\
\text { and without adjuvant chemotherapy }\end{array}$ \\
\hline
\end{tabular}

CS, core tumour stroma; CT, core tumour; DFS, disease-free survival; 5-FU, 5-fluorouracil; IHC, immunohistochemical; IM, invasive margin; OS, overall survival; TAM, tumour-associated macrophage; TAN, tumourassociated neutrophil; TIME, tumour immune microenvironment; TLS, tertiary lymphoid structures.

However, location is relevant-tumours demonstrating a paucity of $\mathrm{CD}^{+}$cells in the tumour core, and lacking the activation markers granzyme-B and IFN $\gamma$, have been termed infiltrated excluded' with worse survival outcomes. ${ }^{1}$ The prognostic associations in chemotherapy-treated patients are less well reported. Retrospective studies have confirmed a positive survival association of increased density $\mathrm{CD}^{+}{ }_{\text {Ст }}$ in patients receiving single agent 5-FU ${ }^{40-43}$ and FOLFOX, ${ }^{44} 45$ although some groups have found no relationship. ${ }^{4647} \mathrm{CD}^{+}{ }_{\text {IM }}$ was not prognostic for single agent 5-FU chemotherapy, ${ }^{40} 48$ and this may reflect the phenomenon of the 'infiltrated excluded' tumour discussed above, which could impact on 5-FU efficacy. In contrast, increased density of $\mathrm{CD}^{+}{ }_{\mathrm{IM}}$ did correlate with improved disease-free survival (DFS) in a large prospective phase III trials of patients receiving adjuvant FOLFOX \pm cetuximab (an epidermal growth factor receptor monoclonal antibody). ${ }^{44} 45$ It is possible that the addition of oxaliplatin to 5-FU may influence the prognostic impact of invasive margin $\mathrm{T}$ cells. Increased density of $\mathrm{CD} 8^{+}{ }_{\mathrm{CS}}$ was positively prognostic in patients with early stage disease receiving adjuvant 5-FU single agent chemotherapy, ${ }^{42} 465051 \pm$ bevacizumab, ${ }^{47}$ and high $\mathrm{CD}^{+}{ }_{\mathrm{CT} / \mathrm{CS} \text { and IM }}$ was associated with improved DFS in patients receiving oxaliplatin doublet adjuvant chemotherapy. ${ }^{44} 4552$ Some studies have reported that the relative survival benefit of adjuvant 5-FU chemotherapy is much greater for patients with increased density of $\mathrm{CD}^{+}{ }_{\text {Ст }}$ compared with patients with low density, ${ }^{53}$ supporting Morris et al's findings, ${ }^{39}$ and suggesting fluoropyrimidines may be more efficacious when a pre-existing $\mathrm{T}_{\mathrm{h}} 1$ response is present. However, a treatment interaction has not been confirmed by other groups. ${ }^{46} \mathrm{CD} 8^{+}{ }_{\mathrm{CT}}$ as a prognostic marker in stage IV patients has shown contradictory results (see table 1). ${ }^{54-56}$ Multiple studies ${ }^{30} 5758$ have correlated high pretreatment $\mathrm{CD}^{+}{ }^{+}$and $\mathrm{CD} 8{ }^{+}$cell density on rectal biopsy with increased response rates to neoadjuvant therapy and improved survival, although this has not been replicated in all reports, ${ }^{31} 59$ and outcomes are mediated by the effects of radiotherapy and are thus outside the scope of this review.

\section{Immunoscore}

The Immunoscore (IS) was designed as a digitally quantified IHC assessment of $\mathrm{CD}^{+}{ }_{\mathrm{CT}+\mathrm{IM}}$ and memory $\mathrm{T}$ cell $\left(\mathrm{CD} 45 \mathrm{RO}^{+}{ }_{\mathrm{CT}+\mathrm{IM}}\right)$ densities added to produce a cumulative score. ${ }^{60}$ It has been validated to show prognostic ability superior to the traditional tumour/node/metastasis (TNM) staging system, ${ }^{61}$ with high scores conferring superior survival. $\mathrm{CD}^{+}$later replaced $\mathrm{CD} 45 \mathrm{RO}^{+}$ due to superior antibody performance ${ }^{3}$ (figure 2 ). Its validity as a prognostic marker in patients receiving adjuvant $5-\mathrm{FU}^{33} 62$ and FOLFOX $^{45} 63$ chemotherapy has been reported, but its role as a predictive marker is less clear. In a recent multinational trial of stage III patients, those with a low IS (0-1) did not benefit from adjuvant chemotherapy (various regimes), whereas those with IS 2-4 did, and the magnitude of the survival benefit was greater the higher the IS. ${ }^{64}$ In high-risk stage II disease, high IS was prognostic, but not a predictive discriminator of 5-FU benefit. ${ }^{65}$
Interestingly, in an analysis of stage III patients in the IDEA collaboration ( 3 months vs 6 months of adjuvant FOLFOX), patients with IS 2-4 had a significantly improved DFS with 6 months vs 3 months of FOLFOX (HR 0.53, p=0.0003), whereas patients with IS $0-1$ did not derive a significant DFS benefit with extended treatment (HR 0.84, $\mathrm{p}=0.27) .{ }^{63}$ This suggests again possible futility of doublet regimes, irrespective of cumulative dose, in immune-excluded disease and a dose-dependent benefit of oxaliplatin regimes in tumours with a baseline cytotoxic $\mathrm{T}$ lymphocyte response.

\section{$\mathrm{CD}^{+} /$Foxp $^{+} \mathrm{T}$ cells}

$\mathrm{CD}^{+}$helper $\mathrm{T}$ cells, which aid tumour immune responses by activation of signalling to facilitate $\mathrm{CD} 8^{+} \mathrm{T}$ cell-mediated cell death, can exert both $\mathrm{T}_{\mathrm{h}} 1$ responses which promote antitumour effects with good prognostic association, ${ }^{66}$ and $\mathrm{T}_{\mathrm{h}} 2$ responses which are tumourigenic. $\mathrm{CD}^{+}{ }_{\mathrm{CT}}$ as a prognostic marker has shown positive association in only half of the studies it has been assessed, and in no studies of $\mathrm{CD}^{+}{ }_{\mathrm{IM}^{\circ}}{ }^{32}$ Adjuvant studies referencing chemotherapy are lacking. Increased primary tumour $\mathrm{CD}^{+}{ }_{\mathrm{CS} \text { and IM }}$ was prognostic in some studies of stage IV patients receiving mixed palliative regimes ${ }^{55}$ but not in other cohorts

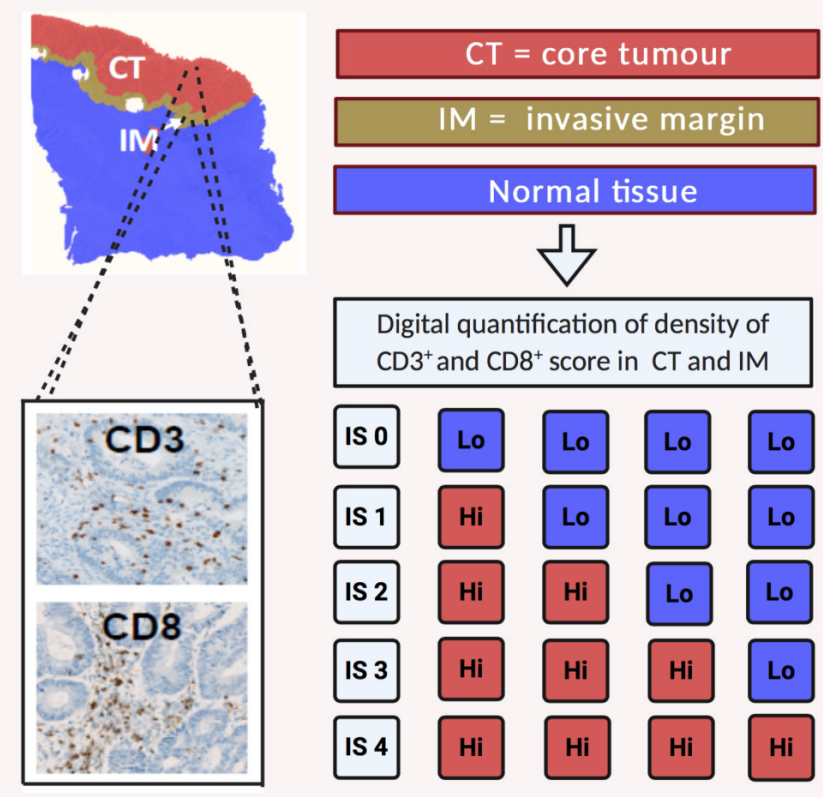

Figure 2 The Immunoscore (IS) is based on the numeration of two lymphocyte populations $\left(\mathrm{CD}^{+}\right.$and $\left.\mathrm{CD}^{+}\right)$in the $\mathrm{CT}$ and IM. Density of cells is determined using an image analysis workstation. Each marker in a specified region is categorised as 'Hi' or 'Lo' based on predetermined cut-off values. Patients are stratified according to a score IS 0 to IS 4 based on the total number of 'Hi' densities observed in the four regions. 
receiving oxaliplatin regimes. ${ }^{56} \mathrm{~T}_{\text {regs }}$ constitute a specific subtype of $\mathrm{CD} 4^{+} \mathrm{T}$ cell, identified by immunoprofile $\mathrm{CD} 25^{+} \mathrm{Foxp} 3^{+}$, and have general immunosuppressive functions, although this can vary depending on marker expression. ${ }^{67}$ Meta-analyses of prognostic studies in CRC has reported a positive association with cancer-specific survival ${ }^{68}$ (CSS) and OS $^{69}$ which is in contrast to other tumour types. High density of Foxp $3^{+}{ }_{\text {CT/CS }}$ has been associated with improved OS in some cohorts receiving adjuvant 5 -FU chemotherapy, ${ }^{40} 424650$ and palliative oxaliplatin, ${ }^{56}$ but not others. ${ }^{417071}$ Some cohorts have suggested that increased Foxp $3^{+}$density may confer a positive prognostic association only in untreated patients, and not in patients receiving chemotherapy, ${ }^{70}$ although true predictive studies are required.

\section{Tumour-associated neutrophil}

Tumour-associated neutrophils (TANs), identified by their markers $\mathrm{CD} 11 \mathrm{~b}^{+}, \mathrm{CD}_{6} 6^{+}$and $\mathrm{Ly} 6 \mathrm{G}^{+}$, are less populous than other cells, and subsets can be either tumour-suppressive or supportive depending on TGF- $\beta$ and IFN- $\gamma$ signalling. ${ }^{72}$ Prognostic studies have reported conflicting results. In stage I-III patients $(\mathrm{n}=1008)$, high TAN $\left(\mathrm{CD}_{66^{+}}{ }_{\mathrm{CT}}\right)$ density conferred an excellent prognosis, and no benefit from adjuvant chemotherapy, whereas low density conferred worse prognosis and poorer survival in patients receiving adjuvant chemotherapy ${ }^{70}$ However, this unexpected result may be a reflection of treatment bias and lack of adjustment for tumour stage and necrosis, which are associated with TAN density. ${ }^{73}$ In a contradictory smaller cohort of stage III patients, high $\mathrm{TAN}_{\mathrm{CT}}$ density was reported as a negative prognostic marker in patients undergoing surgery (DFS HR 3.0, $\mathrm{p}=0.07$ ). However, this impact was mitigated by the use of adjuvant 5 -FU, whereby patients with high TAN $_{\text {CT }}$ had improved prognosis. ${ }^{74}$ High CD $66 \mathrm{~b}^{+}{ }_{\text {IM }}$ was also a positive prognostic and predictive marker in stage III patients receiving adjuvant 5 -FU. ${ }^{75}$ Contradictory results may also be explained in this and other studies by variations in methodology, including different prognostic associations depending on assessment in invasive margin or core tumour, ${ }^{73}$ and variable marker categorisation.

\section{Tumour-associated macrophages}

Tumour-associated macrophages (TAMs), often identified by the non-specific $\mathrm{CD} 68^{+}$monocyte lineage marker, are broadly grouped into two phenotypes. The classically activated (M1) type (surface markers iNOS, CD86 ${ }^{+}, \mathrm{CD} 169^{+}$) that stimulate antitumour immune responses, and the alternatively activated (M2) type (surface markers CD $163^{+}, \mathrm{CD} 206^{+}, \mathrm{CD} 204^{+}$) that enhance tumour progression and suppress immune response (eg, NK and T cell mediated killing). ${ }^{76}$ Increased $\mathrm{CD} 68^{+}{ }_{\mathrm{IM}}$ density was a positive predictive marker of 5-FU benefit in a small cohort, and in a companion in vitro study, 5-FU and M1-macrophages showed synergistic impact on cell death in CRC cell lines. ${ }^{75} \mathrm{M} 2_{\mathrm{CT}}$ infiltration has been reported as negatively prognostic in several studies of patients treated with systemic chemotherapy. ${ }^{5570} 7778$ In vitro work has suggested that M2 macrophages confer resistance to 5 -FU, ${ }^{79}$ and some studies suggest a negative predictive relationship. ${ }^{70}$ Feng et a $l^{77}$ reported high $\mathrm{CD} 206^{+}: \mathrm{CD} 68^{+}$ratio (increased proportion of M2 macrophages) was a marker for poorer DFS and OS in stage II disease, although also predicted a significant survival benefit from adjuvant 5 -FU-based chemotherapy versus observation (DFS HR 0.42, $\mathrm{p}=0.003$ ) which was not present in the better prognostic group with a low ratio (HR $0.99, \mathrm{p}=0.99$ ). Oxaliplatin plus trifluridine/tipiracil (an antimetabolite) depletes M2 macrophages, resulting in higher $\mathrm{CD} 8^{+}$ infiltration and better therapeutic efficacy. ${ }^{80}$ Further exploration in patient cohorts using differential chemotherapy regimes is required.

\section{CD45RO ${ }^{+} \mathrm{T}$ cells}

Central and effector memory T cells (characterised by CD45RO ${ }^{+}$ marker) drive secondary immune responses post exposure to primary antigens. Meta-analyses suggest a positive prognostic association for increased density of these cells both in the core tumour and invasive margin. ${ }^{32}$ High density of primary tumour $\mathrm{CD} 45 \mathrm{RO}^{+}{ }_{\mathrm{CT}}^{42}{ }^{43}$ and $\mathrm{CD} 45 \mathrm{RO}^{+}{ }_{\mathrm{IM}} 71$ is an independent prognostic factor for improved OS in early stage disease patients receiving 5 -FU. High density was associated with better survival in patients with stage IV CRC undergoing adjuvant oxaliplatin or irinotecan chemotherapy post-curative intent resection (estimated 3-year survival $62 \%$ vs $27 \%, \mathrm{p}=0.007) .{ }^{54} \mathrm{High} \mathrm{CCR} 7^{+}$CS (used to identify $\mathrm{CD} 8^{+}$naïve and central memory $\mathrm{T}$ cells) was associated with improved OS in patients receiving palliative oxaliplatin-based regimes. ${ }^{81}$

\section{Gamma delta $(\gamma \delta)$ T cells}

Gamma delta $T$ cells are a rare subset of predominantly mucosal CD8 ${ }^{-}{ }^{-} 4^{-} \mathrm{T}$ cells with a broad functional role in cytokine (IFN- $\gamma$, tumour necrosis factor (TNF)- $\alpha$, interleukin (IL)-17) and chemokine (RANTES, IP-10, lymphotactin) production, cytolysis and coordination of antigen presentation. ${ }^{82}$ In vivo studies show that ICD-inducing chemotherapy causes a rapid invasion of $\gamma \delta \mathrm{T}$ lymphocytes prior to the invasion of $\mathrm{CD} 8^{+} \mathrm{T}$ cells, and that in TCR $\delta^{-/-}$mice, the therapeutic efficacy of chemotherapy was reduced. ${ }^{83}$ Increased expression of $\gamma \delta \mathrm{T}$ cells has been associated with improved DFS in patients with CRC. ${ }^{84}$ While results from CRC cohorts receiving chemotherapy are under-reported, a series $(n=463)$ of patients with gastric cancer receiving adjuvant 5 -FU chemotherapy suggest a significant survival advantage of chemotherapy versus observation if infiltrating $\gamma \delta \mathrm{T}$ cells were increased. $^{85}$

\section{B cells}

$\mathrm{B}$ cells also recognise tumour antigens, produce tumour-specific antibodies and are identified through $\mathrm{CD} 19^{+}, \mathrm{CD} 20^{+}$and $\mathrm{CD} 78^{+}$markers. High CD $20^{+}$CS has been associated with better prognosis in CRC, ${ }^{86}$ as has the presence of TLSs, which contain concentrated B cells. ${ }^{87}$ However, CD20 ${ }^{+}{ }_{\text {CT or IM }}$ was not prognostic in patients receiving adjuvant FOLFOX. ${ }^{45}$

\section{Immune checkpoints}

Multiple stimulatory and inhibitory immune checkpoints, crucial for self-tolerance, and co-opted by tumours to evade immunosurveillance, have been identified in the TIME. One such checkpoint, programmed death-ligand 1 (PD-L1), is predominantly derived from the immune infiltrate ${ }^{88}$ not tumour cells, in CRC. Immunodeficient murine xenograft models of PD-L1 knockout tumours display resistance to oxaliplatin, ${ }^{89}$ which contrasts with models in other tumour types. In early stage patients receiving 5-FU chemotherapy, high tumour PD-L1 was not prognostic in some studies, ${ }^{40} 42$ although negatively impacted on DFS in another stage III cohort receiving adjuvant chemotherapy. ${ }^{90}$ In contrast, PD-L1 expression on immune infiltrating mononuclear cells was associated with longer DFS. Dunne et a ${ }^{91}$ reported that in stage III CRC ( $\mathrm{n}=201)$, PD-L1 $1_{\text {low }}$ tumours conferred a significant DFS benefit from adjuvant chemotherapy versus observation (adjusted HR 0.44, $\mathrm{p}=0.0062$ ), and the use of adjuvant chemotherapy was able to overcome the negative prognostic impact of 
low PD-L1. However, in contrast, PD-L1 $1_{\text {high }}$ expression resulted in inferior DFS post adjuvant chemotherapy versus observation (unadjusted HR 4.95, 95\% CI 1.10 to 22.35 , p=0.02), although the significance was lost on multivariate analysis. This is one of the first series to suggest a possible detrimental effect of chemotherapy in tumours which overexpress PD-L1.

\section{Immune markers associated with microsatellite instability}

Tumours harbouring microsatellite instability (MSI) have defects in the DNA mismatch repair system (dMMR), and thus display a hypermutable phenotype. The differential improved survival in patients with early stage dMMR tumours has been extensively reported and is partly attributable to increased immune stimulation in these tumours due to the increased neoantigen load. MSI tumours have a dense infiltration of $\mathrm{CD}^{+}{ }^{+}$cells, ${ }^{92}$ a $\mathrm{T}_{\mathrm{h}} 1$ cytokine response, and also overexpress many inhibitory immune checkpoints (including PD-1, PD-L1, CTLA-4, LAG-3 and IDO). ${ }^{93}$ However, MSI tumours are more chemoresistant to 5-FU than microsatellite stable (MSS) lines in preclinical models. ${ }^{94}$ The relative survival benefit from FOLFOX compared with 5-FU is much greater in stage II-III dMMR patients compared with pMMR, ${ }^{95}$ suggesting possible resistance to 5-FU alone. However, in a recent report from the FoXTROT trial, dMMR colon cancers showed significantly reduced pathological response rates to neoadjuvant oxaliplatin doublet chemotherapy than pMMR, ${ }^{96}$ and clinical progression through this chemotherapy regime was more common in dMMR than pMMR rectal cancers $(29 \%$ vs $0 \%, \mathrm{p}=0.0001) .{ }^{97}$
In contrast, in the metastatic setting, MSI status did not affect response rates to palliative FOLFOX chemotherapy. ${ }^{98}$ Regarding irinotecan therapy, in both cell lines and tumour xenografts, dMMR tumours are more sensitive to irinotecan than MMR proficient (pMMR) lines. ${ }^{99}{ }^{100}$ In a small retrospective cohort, response rates to palliative 5-FU plus irinotecan were much higher in MSI than MSS disease (57\% vs $10 \%$, $\mathrm{p}=0.009),{ }^{101}$ and DFS was longer in MSI tumours receiving an irinotecan containing regime in a separate cohort. ${ }^{102}$ In a large adjuvant phase III trial, only patients with dMMR tumours received a DFS benefit from adding irinotecan to 5 -FU, ${ }^{103}$ but this MSI/treatment interaction was not confirmed in another similar trial. ${ }^{104}$ The relevance of immunological variation on chemotherapeutic response in the context of genetic alterations is largely unknown.

\section{Immunogenic Cell Death markers}

ICD is the cornerstone of the immunomodulatory action of oxaliplatin and associated markers are potential predictive biomarkers (figure 3). DC activation is a key step in ICD. However, identification of DCs, which show functional diversity and heterogeneous activation states, can be challenging and markers are variably reported between studies and may account for conflicting results reporting both $\operatorname{good}^{105-109}$ and bad $^{110}$ prognostic association. In vivo studies have demonstrated that blockade of surface calreticulin exposure ${ }^{111}$ and HMGB1dependent TLR-4 signalling, ${ }^{112}$ both key steps in ICD, severely compromised the cytotoxicity of oxaliplatin chemotherapy.

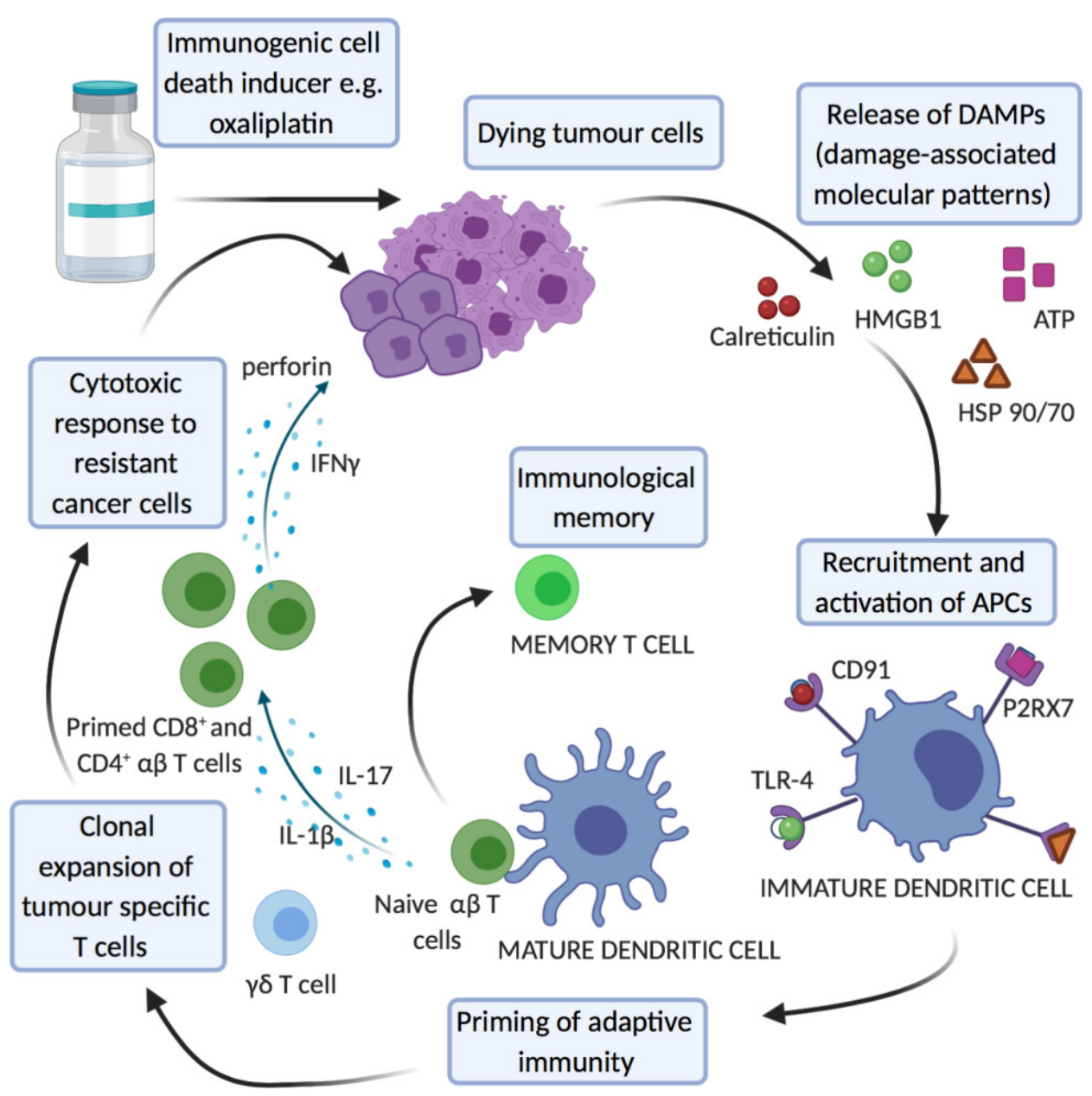

Figure 3 Key cells and pathways in immunogenic cell death as potential predictive biomarkers. IFN $\gamma$, interferon; IL, interleukin. 
Stromal calreticulin expression is associated with infiltration of $\mathrm{CD} 45 \mathrm{RO}^{+}$cells and improved OS in univariate analysis in patients receiving adjuvant 5 -FU. ${ }^{113}$

\section{Stromal markers}

The tumour stroma plays a direct and indirect role in modulating response to immunomodulatory chemotherapy. De novo drug resistance may occur from environment-mediated phenomena, where cancer cells are protected from treatmentinduced apoptosis by 'barriers', including either soluble secreted factors or cell-adhesion-mediated mechanisms. ${ }^{114}$ The tumour:stroma percentage is a validated prognostic marker, with increased stromal percentage associated with poorer prognosis, including in chemotherapy-treated patients. ${ }^{115}$ Cancer-associated fibroblasts (CAFs) are a heterogeneous group of fibroblast-like cells that release certain cytokines, growth factors and proinflammatory factors. In vitro cell line studies suggest CAFs trigger a JAK/STAT pathway signalling cascade that leads to reduced response rates to oxaliplatin and 5-FU, ${ }^{116}$ and stromal CAF-derived conditioned medium primed the growth of cancer stem cells after treatment with 5 -FU and oxaliplatin, thus increasing their inherent chemoresistance. ${ }^{117}$ High CAF infiltration is associated with worse DFS in adjuvant-treated patients ${ }^{118}$ and associated-induced expression of their surrogate markers smooth muscle actin and survivin have been related to worse survival in $5-\mathrm{FU}^{119}$ and oxaliplatin-treated advanced patients. ${ }^{120}$

\section{Genomic markers and transcriptomic profiles}

Recent advances in high-throughput gene testing technology have led to the development of some molecular signatures for chemotherapy prediction. Increased expression of infiltrating immune cells, as identified by CIBERSOrT, showed a trend to improved overall survival in patients receiving chemotherapy. ${ }^{121}$ Multiple classifications of CRC, based on molecular transcriptomic data, have been proposed in recent years, and unified into the Consensus Molecular Subtypes (CMS). This incorporates gene expression profiles from the tumour, stroma and immune cells to differentiate four groups (CMS1-4) and are highly correlated with immune cell infiltration patterns. ${ }^{122}$ The CMS1 subgroup (MSI-like) is enriched for genes coding for $\mathrm{CD} 8^{+}$and $\mathrm{CD} 68^{+}$ cells, T-cell attracting chemokines, TLSs and Th1 cytokines. The CMS4 subgroup (mesenchymal) is enriched for expression of genes encoding $\mathrm{CD} 8^{+}$cells, MDSCs, $\mathrm{T}_{\text {regs }}, \mathrm{T}_{\mathrm{h}} 17^{+}$cells, angiogenic factors and immunosuppressive molecules (eg, TGF 31 ). Both CMS2 (canonical) and CMS3 (metabolic) subgroups exhibit low-immune and low-inflammatory signatures. In a retrospective taxonomy study, only CMS2 and 3 subgroups derived a benefit from adjuvant chemotherapy (unspecified) in stage III disease, with CMS4 showing a trend to benefit. ${ }^{123}$ Song et al ${ }^{124}$ used an alternative transcriptomic classifier (CRCA) to examine patients in the NSABP-07 trial (adjuvant FOLFOX vs 5-FU), and reported only patients with an 'enterocyte' subtype (with immune features similar to the 'cold' CMS2) derived a benefit from the addition of oxaliplatin, with a significant interaction test. The same group repeated the analysis using patients enrolled on the MOSAIQ trial (adjuvant CAPOX vs capecitabine) but did not find any association, ${ }^{125}$ which may be due to different fluoropyrimidine use or oxaliplatin schedule, which have shown different interactions in other immune biomarker studies. ${ }^{36}$ CMS1 patients have worse OS with FOLFIRI-based regimes compared with the other CMS subtypes in the FIRE-3 trial $^{126}$; however, they also show improved OS with the addition of bevacizumab in the metastatic setting. ${ }^{127}$ Published studies suggest a trend to 5FU/oxaliplatin resistance in CMS4 (or similar classifier) patients, both in the adjuvant ${ }^{127} 128$ and metastatic setting, ${ }^{129}$ where first-line irinotecan regimes showed better response rates and survival. ${ }^{130} 131$

\section{IMMUNE INFILTRATE IN RESECTED METASTASES}

Several reports have assessed the prognostic and predictive impact of the TIME from resected metastases, predominantly liver metastases, ${ }^{132}$ which appears to correlate with the primary tumour. However, many of the studies include patients receiving neoadjuvant therapy, which can alter the immune infiltrate substantially. Metastatic disease has a different immunological milieu which is defined by tumour immune evasion. Liver metastases with pretreatment high Immunoscore (and high $\mathrm{CD}^{+}, \mathrm{CD} 8^{+}$, and $\mathrm{CD} 20^{+}$cells $^{133}$ ) are associated with increased response to chemotherapy $(p=0.009)$ and improved DFS and OS. ${ }^{55}$ The type of postoperative chemotherapy/adjunct did not impact survival. However, a high IS is not tantamount to excellent prognosis in this setting (as opposed to with early stage disease) as most patients relapsed after surgery. The authors showed the density of $\mathrm{CD} 8^{+}: \mathrm{CD} 20^{+}{ }_{\mathrm{CT}+\mathrm{IM}}$ to be an additional strong prognostic discriminator. A high 'density score' (based on a cumulative density of $\mathrm{CD}^{+}, \mathrm{CD} 8^{+}$and granzyme $\mathrm{B}$ in liver metastases) was also reported by Halama et $a l^{134}$ to have significant prognostic ability in stage IV patients receiving any regime of chemotherapy (HR OS $0.06, \mathrm{p}<0.01$ ).

\section{CONCLUSIONS}

Here, we have reviewed CRC studies focusing on the TIME and found that the prognostic ability of these markers in CRC is mediated in the context of chemotherapy, and true predictive studies are under-reported. While prognostic biomarkers have been used as a surrogate for predictive markers, with an assumption that patients with 'poor' prognosis will gain a greater absolute benefit from chemotherapy, this may be untrue, especially if the biomarker is also a marker of therapy resistance. Nevertheless, current reports indicate that the relative benefit of 5-FU chemotherapy may be enhanced in the context of some pre-existing $\mathrm{CD} 8^{+} / \mathrm{CD}^{+}{ }^{+}$infiltration in core tumour, but may be unnecessary or importantly even detrimental in the milieu of a highly inflamed TIME. CRCs with high immunosuppressive pathways may also be more resistant to oxaliplatin doublets. Furthermore, chemotherapy may improve prognosis in cancers driven by specific immune cell populations, such as TAMs and TANs. The emerging move

\section{Take home messages}

- The tumour immune microenvironment has an important role to play in mediating cytotoxic chemotherapy response and primary resistance.

- Many chemotherapy agents used in colorectal cancer have local and systemic immunomodulatory effects.

- Baseline tumour immune cells, including T cell subsets, tumour-associated neutrophils and macrophages, may represent potential predictive biomarker predicting response and resistance to cytotoxic chemotherapy.

- Prospective trials using standardised validated markers, such as the Immunoscore, are required to rationalise the use of adjuvant chemotherapy and target different palliative chemotherapy regimes and adjuncts to patients more likely to respond. 
to standardise assessment of TILs/IHC-based markers in CRC reporting has the potential for more robust prospective trials. Such trials are needed to develop better clinical biomarkers for therapy benefit and cytotoxic effects of chemotherapy. Patients likely having adverse effects may require de-escalated or even no therapy, and some may require alternative or combination agents, which have shown early promise. ${ }^{135}$ Significant research and development is in progress with regard to such adjuncts, which include various combination approaches with synergistic benefits ${ }^{136}$ and novel immunotherapies, to improve precision medicine in the future.

\section{Handling editor Runjan Chetty.}

Contributors All authors have contributed to the production of this manuscript. Images created with Biorender.com.

Funding The authors have not declared a specific grant for this research from any funding agency in the public, commercial or not-for-profit sectors.

Competing interests None declared.

Patient consent for publication Not required.

Provenance and peer review Not commissioned; internally peer reviewed.

Open access This is an open access article distributed in accordance with the Creative Commons Attribution Non Commercial (CC BY-NC 4.0) license, which permits others to distribute, remix, adapt, build upon this work non-commercially, and license their derivative works on different terms, provided the original work is properly cited, appropriate credit is given, any changes made indicated, and the use is non-commercial. See: http://creativecommons.org/licenses/by-nc/4.0/.

ORCID iD

Kate Wilkinson http://orcid.org/0000-0001-8318-4615

\section{REFERENCES}

1 Binnewies M, Roberts EW, Kersten K, et al. Understanding the tumor immune microenvironment (time) for effective therapy. Nat Med 2018;24:541-50.

2 Andrews MC, Reuben A, Gopalakrishnan V, et al. Concepts collide: genomic, immune, and microbial influences on the tumor microenvironment and response to cancer therapy. Front Immunol 2018;9:946.

3 Galon J, Mlecnik B, Bindea G, et al. Towards the introduction of the 'Immunoscore' in the classification of malignant tumours. J Pathol 2014;232:199-209.

4 Klintrup K, Mäkinen JM, Kauppila S, et al. Inflammation and prognosis in colorectal cancer. Eur J Cancer 2005;41:2645-54.

5 Jass JR. Lymphocytic infiltration and survival in rectal cancer. J Clin Pathol 1986;39:585-9.

6 Nolte S, Zlobec I, Lugli A, et al. Construction and analysis of tissue microarrays in the era of digital pathology: a pilot study targeting $\mathrm{Cdx} 1$ and $\mathrm{CDX} 2$ in a colon cancer cohort of 612 patients. J Pathol Clin Res 2017;3:58-70.

7 Newman AM, Liu CL, Green MR, et al. Robust enumeration of cell subsets from tissue expression profiles. Nat Methods 2015;12:453-7.

8 Becht E, Giraldo NA, Lacroix L, et al. Estimating the population abundance of tissueinfiltrating immune and stromal cell populations using gene expression. Genome Biol 2016;17:218.

9 Hwang B, Lee JH, Bang D. Single-Cell RNA sequencing technologies and bioinformatics pipelines. Exp Mol Med 2018;50:96.

10 Bracci L, Schiavoni G, Sistigu A, et al. Immune-based mechanisms of cytotoxic chemotherapy: implications for the design of novel and rationale-based combined treatments against cancer. Cell Death Differ 2014;21:15-25.

11 Galluzzi L, Buqué A, Kepp 0, et al. Immunological effects of conventional chemotherapy and targeted anticancer agents. Cancer Cell 2015:28:690-714

12 Zitvogel L, Galluzzi L, Smyth MJ, et al. Mechanism of action of conventional and targeted anticancer therapies: reinstating immunosurveillance. Immunity 2013;39:74-88.

13 Maeda K, Hazama S, Tokuno K, et al. Impact of chemotherapy for colorectal cancer on regulatory T-cells and tumor immunity. Anticancer Res 2011;31:4569-74.

14 Liu WM, Fowler DW, Smith P, et al. Pre-Treatment with chemotherapy can enhance the antigenicity and immunogenicity of tumours by promoting adaptive immune responses. Br J Cancer 2010;102:115-23.
15 Ohtsukasa S, Okabe S, Yamashita H, et al. Increased expression of CEA and MHC class I in colorectal cancer cell lines exposed to chemotherapy drugs. J Cancer Res Clin Oncol 2003;129:719-26.

16 Lesterhuis WJ, Punt CJA, Hato SV, et al. Platinum-based drugs disrupt STAT6mediated suppression of immune responses against cancer in humans and mice. $J$ Clin Invest 2011;121:3100-8.

17 Casares N, Pequignot MO, Tesniere A, et al. Caspase-dependent immunogenicity of doxorubicin-induced tumor cell death. J Exp Med 2005;202:1691-701.

18 Tesniere A, Schlemmer F, Boige V, et al. Immunogenic death of colon cancer cells treated with oxaliplatin. Oncogene 2010;29:482-91.

19 Kroemer G, Galluzzi L, Kepp 0, et al. Immunogenic cell death in cancer therapy. Annu Rev Immunol 2013;31:51-72.

20 Hato SV, Khong A, de Vries IJM, et al. Molecular pathways: the immunogenic effects of platinum-based chemotherapeutics. Clin Cancer Res 2014;20:2831-7.

21 Guan Y, Kraus SG, Quaney MJ, et al. Folfox chemotherapy ameliorates CD8 T lymphocyte exhaustion and enhances checkpoint blockade efficacy in colorectal cancer. Front Oncol 2020;10:586.

22 Vincent J, Mignot G, Chalmin F, et al. 5-Fluorouracil selectively kills tumor-associated myeloid-derived suppressor cells resulting in enhanced T cell-dependent antitumor immunity. Cancer Res 2010;70:3052-61.

23 Ghiringhelli F, Bruchard M, Apetoh L. Immune effects of 5-fluorouracil: ambivalence matters. Oncoimmunology 2013;2:e23139

24 Bruchard M, Mignot G, Derangère V, et al. Chemotherapy-triggered cathepsin B release in myeloid-derived suppressor cells activates the NLRP3 inflammasome and promotes tumor growth. Nat Med 2013;19:57-64.

25 Kanterman J, Sade-Feldman M, Biton M, et al. Adverse immunoregulatory effects of 5FU and CPT11 chemotherapy on myeloid-derived suppressor cells and colorectal cancer outcomes. Cancer Res 2014;74:6022-35.

26 Iwai T, Sugimoto M, Wakita D, et al. Topoisomerase I inhibitor, irinotecan, depletes regulatory T cells and up-regulates MHC class I and PD-L1 expression, resulting in a supra-additive antitumor effect when combined with anti-PD-L1 antibodies. Oncotarget 2018;9:31411-21.

27 Tanis E, Julié C, Emile J-F, et al. Prognostic impact of immune response in resectable colorectal liver metastases treated by surgery alone or surgery with perioperative FOLFOX in the randomised EORTC study 40983. Eur J Cancer 2015;51:2708-17.

28 Donadon $\mathrm{M}$, Hudspeth $\mathrm{K}$, Cimino $\mathrm{M}$, et al. Increased infiltration of natural killer and T cells in colorectal liver metastases improves patient overall survival. J Gastrointest Surg 2017;21:1226-36.

29 Ledys F, Klopfenstein Q, Truntzer C, et al. Ras status and neoadjuvant chemotherapy impact CD8+ cells and tumor HLA class I expression in liver metastatic colorectal cancer. J Immunother Cancer 2018;6:123.

30 Teng F, Mu D, Meng X, et al. Tumor infiltrating lymphocytes (TILs) before and after neoadjuvant chemoradiotherapy and its clinical utility for rectal cancer. Am J Cancer Res 2015;5:2064-74.

31 Zhang S, Bai W, Tong $X$, et al. Correlation between tumor microenvironmentassociated factors and the efficacy and prognosis of neoadjuvant therapy for rectal cancer. Oncol Lett 2019;17:1062-70.

32 Alexander PG, McMillan DC, Park JH. The local inflammatory response in colorectal cancer - Type, location or density? A systematic review and meta-analysis. Cancer Treat Rev 2020;83:101949

33 Park JH, McMillan DC, Edwards J, et al. Comparison of the prognostic value of measures of the tumor inflammatory cell infiltrate and tumor-associated stroma in patients with primary operable colorectal cancer. Oncoimmunology 2016:5:e1098801.

34 Hynes SO, Coleman HG, Kelly PJ, et al. Back to the future: routine morphological assessment of the tumour microenvironment is prognostic in stage II/III colon cancer in a large population-based study. Histopathology 2017;71:12-26.

35 Cha YJ, Park EJ, Baik SH, et al. Clinical significance of tumor-infiltrating lymphocytes and neutrophil-to-lymphocyte ratio in patients with stage III colon cancer who underwent surgery followed by FOLFOX chemotherapy. Sci Rep 2019:9:11617.

36 Roseweir AK, Park JH, Hoorn ST, et al. Histological phenotypic subtypes predict recurrence risk and response to adjuvant chemotherapy in patients with stage III colorectal cancer. J Pathol Clin Res 2020;6:283-96.

37 Pentheroudakis G, Raptou G, Kotoula V, et al. Immune response gene expression in colorectal cancer carries distinct prognostic implications according to tissue, stage and site: a prospective retrospective translational study in the context of a Hellenic cooperative Oncology group randomised trial. PLoS One 2015; 10:e0124612

38 Shibutani M, Maeda K, Nagahara H, et al. Tumor-Infiltrating lymphocytes predict the chemotherapeutic outcomes in patients with stage IV colorectal cancer. In Vivo 2018:32:151-8

39 Morris M, Platell C, lacopetta B. Tumor-Infiltrating lymphocytes and perforation in colon cancer predict positive response to 5 -fluorouracil chemotherapy. Clin Cancer Res 2008;14:1413-7.

40 Miller TJ, McCoy MJ, Hemmings C, et al. The prognostic value of cancer stem-like cell markers Sox2 and CD133 in stage III colon cancer is modified by expression of the immune-related markers FOXP3, PD-L1 and CD3. Pathology 2017;49:721-30. 
41 Sinicrope FA, Rego RL, Ansell SM, et al. Intraepithelial effector (CD3+)/regulatory (FoxP3+) T-cell ratio predicts a clinical outcome of human colon carcinoma. Gastroenterology 2009;137:1270-9.

42 Feng Y, Li Y, Cai S, et al. Immunological nomograms predicting prognosis and guiding adjuvant chemotherapy in stage II colorectal cancer. Cancer Manag Res 2019:11:7279-94.

43 Peng R-Q, Wu X-J, Ding Y, et al. Co-expression of nuclear and cytoplasmic HMGB1 is inversely associated with infiltration of CD45RO+ $T$ cells and prognosis in patients with stage IIIB colon cancer. BMC Cancer 2010;10:496.

44 Reichling C, Taieb J, Derangere V, et al. Artificial intelligence-guided tissue analysis combined with immune infiltrate assessment predicts stage III colon cancer outcomes in PETACC08 study. Gut 2020;69:681-90.

45 Sinicrope FA, Shi Q, Hermitte F, et al. Contribution of immunoscore and molecular features to survival prediction in stage III colon cancer. JNCI Cancer Spectr 2020:4:pkaa023.

46 Berntsson J, Svensson MC, Leandersson K, et al. The clinical impact of tumourinfiltrating lymphocytes in colorectal cancer differs by anatomical subsite: a cohort study. Int J Cancer 2017;141:1654-66.

47 Glaire MA, Domingo E, Sveen A, et al. Tumour-infiltrating CD8 ${ }^{+}$lymphocytes and colorectal cancer recurrence by tumour and nodal stage. $\mathrm{Br} J$ Cancer 2019;121:474-82.

48 Laghi L, Bianchi P, Miranda E, et al. Cd3 + cells at the invasive margin of deeply invading (pT3-T4) colorectal cancer and risk of post-surgical metastasis: a longitudinal study. Lancet Oncol 2009;10:877-84.

49 Emile J-F, Julié C, Le Malicot K, et al. Prospective validation of a lymphocyte infiltration prognostic test in stage III colon cancer patients treated with adjuvant FOLFOX. Eur J Cancer 2017;82:16-24.

50 Yoon HH, Orrock JM, Foster NR, et al. Prognostic impact of Foxp3+ regulatory T cells in relation to $\mathrm{CD} 8+\mathrm{T}$ lymphocyte density in human colon carcinomas. PLoS One 2012; 7:e42274.

51 Sperlich A, Balmert A, Doll D, et al. Genetic and immunological biomarkers predict metastatic disease recurrence in stage III colon cancer. BMC Cancer 2018;18:998.

52 Fountzilas E, Kotoula V, Tikas I, et al. Prognostic significance of tumor genotypes and CD8+ infiltrates in stage I-III colorectal cancer. Oncotarget 2018;9:35623-38.

53 Prall F, Dührkop T, Weirich V, et al. Prognostic role of CD8+ tumor-infiltrating lymphocytes in stage III colorectal cancer with and without microsatellite instability. Hum Pathol 2004;35:808-16.

54 Lee W-S, Kang M, Baek J-H, et al. Clinical impact of tumor-infiltrating lymphocytes for survival in curatively resected stage IV colon cancer with isolated liver or lung metastasis. Ann Surg Oncol 2013;20:697-702.

55 Kwak Y, Koh J, Kim D-W, et al. Immunoscore encompassing CD3+ and CD8+ T cell densities in distant metastasis is a robust prognostic marker for advanced colorectal cancer. Oncotarget 2016;7:81778-90.

56 Correale P, Rotundo MS, Del Vecchio MT, et al. Regulatory (Foxp3+) T-cell tumo infiltration is a favorable prognostic factor in advanced colon cancer patients undergoing chemo or chemoimmunotherapy. J Immunother 2010;33:435-41.

57 Anitei M-G, Zeitoun G, Mlecnik B, et al. Prognostic and predictive values of the immunoscore in patients with rectal cancer. Clin Cancer Res 2014:20:1891-9.

58 Shinto E, Hase K, Hashiguchi Y, et al. Cd8+ and Foxp3+ tumor-infiltrating T cells before and after chemoradiotherapy for rectal cancer. Ann Surg Oncol 2014;21:414-21.

59 McCoy MJ, Hemmings C, Anyaegbu CC, et al. Tumour-Infiltrating regulatory T cell density before neoadjuvant chemoradiotherapy for rectal cancer does not predict treatment response. Oncotarget 2017;8:19803-13.

60 Galon J, Costes A, Sanchez-Cabo F, et al. Type, density, and location of immune cells within human colorectal tumors predict clinical outcome. Science 2006:313:1960-4.

61 Pagès F, Kirilovsky A, Mlecnik B, et al. In situ cytotoxic and memory T cells predict outcome in patients with early-stage colorectal cancer. J Clin Oncol 2009;27:5944-51.

62 Wirta E-V, Seppälä T, Friman M, et al. Immunoscore in mismatch repair-proficient and -deficient colon cancer. J Pathol Clin Res 2017;3:203-13.

63 Pagès $F$, André $T$, Taieb J, et al. Prognostic and predictive value of the Immunoscore in stage III colon cancer patients treated with oxaliplatin in the prospective IDEA France PRODIGE-GERCOR cohort study. Ann Oncol 2020:31:921-9.

64 Mlecnik B, Bifulco C, Bindea G, et al. Multicenter International Society for immunotherapy of cancer study of the consensus immunoscore for the prediction of survival and response to chemotherapy in stage III colon cancer. J Clin Oncol 2020;38:3638-51.

65 Galon J, Hermitte F, Mlecnik B, et al. Immunoscore clinical utility to identify good prognostic colon cancer stage II patients with high-risk clinico-pathological features for whom adjuvant treatment may be avoided [abstract]. J Clin Oncol 2019;37 (Supp 4):P487

66 Ling A, Lundberg IV, Eklöf $\mathrm{V}$, et al. The infiltration, and prognostic importance, of Th1 lymphocytes vary in molecular subgroups of colorectal cancer. J Pathol Clin Res 2016:2:21-31.

67 Saito T, Nishikawa H, Wada H, et al. Two FOXP3(+)CD4(+) T cell subpopulations distinctly control the prognosis of colorectal cancers. Nat Med 2016;22:679-84.
68 Xu P, Fan W, Zhang Z, et al. The clinicopathological and prognostic implications of FoxP3 ${ }^{+}$regulatory $T$ cells in patients with colorectal cancer: a meta-analysis. Front Physiol 2017:8:950

69 Ling Z-A, Zhang L-J, Ye Z-H, et al. Immunohistochemical distribution of Foxp3+ regulatory T cells in colorectal cancer patients. Int J Clin Exp Pathol 2018:11:1841-54.

70 Ye L, Zhang T, Kang Z, et al. Tumor-Infiltrating immune cells act as a marker for prognosis in colorectal cancer. Front Immunol 2019:10:2368

71 Kim Y, Bae JM, Li G, et al. Image analyzer-based assessment of tumor-infiltrating $T$ cell subsets and their prognostic values in colorectal carcinomas. PLoS One 2015:10:e0122183.

72 Mizuno R, Kawada K, Itatani Y, et al. The role of tumor-associated neutrophils in colorectal cancer. Int J Mol Sci 2019:20:529.

73 Wikberg ML, Ling A, Li X, et al. Neutrophil infiltration is a favorable prognostic factor in early stages of colon cancer. Hum Pathol 2017:68:193-202.

74 Galdiero MR, Bianchi P, Grizzi F, et al. Occurrence and significance of tumorassociated neutrophils in patients with colorectal cancer. Int J Cancer 2016;139:446-56.

75 Malesci A, Bianchi P, Celesti G, et al. Tumor-associated macrophages and response to 5-fluorouracil adjuvant therapy in stage III colorectal cancer. Oncoimmunology 2017;6:e1342918.

76 Edin S, Wikberg ML, Dahlin AM, et al. The distribution of macrophages with a M1 or M2 phenotype in relation to prognosis and the molecular characteristics of colorecta cancer. PLoS One 2012:7:e47045.

77 Feng Q, Chang W, Mao Y, et al. Tumor-Associated macrophages as prognostic and predictive biomarkers for postoperative adjuvant chemotherapy in patients with stage II colon cancer. Clin Cancer Res 2019;25:3896-907.

78 Basile D, Polano M, Buriolla S, et al. Prognostic role of macrophage infiltration and monocyte-to-lymphocyte ratio in stage III colon cancer: the mirror study [abstract]. J Clin Oncol 2020;38 (Supp 15):P16118

79 Wei C, Yang C, Wang S, et al. M2 macrophages confer resistance to 5-fluorouracil in colorectal cancer through the activation of CCL22/PI3K/AKT signaling. Onco Targets Ther 2019:12:3051-63.

80 Limagne E, Thibaudin M, Nuttin L, et al. Trifluridine/Tipiracil plus oxaliplatin improves PD-1 blockade in colorectal cancer by inducing immunogenic cell death and depleting macrophages. Cancer Immunol Res 2019;7:1958-69.

81 Correale P, Rotundo MS, Botta C, et al. Tumor infiltration by T lymphocytes expressing chemokine receptor 7 (CCR7) is predictive of favorable outcome in patients with advanced colorectal carcinoma. Clin Cancer Res 2012:18:850-7.

82 Lo Presti E, Pizzolato G, Corsale AM, et al. $\gamma \delta$ T Cells and Tumor Microenvironment: From Immunosurveillance to Tumor Evasion. Front Immunol 2018:9:1395.

83 Ma Y, Aymeric L, Locher C, et al. Contribution of IL-17-producing $\gamma \delta$ T cells to the efficacy of anticancer chemotherapy. J Exp Med 2011:208:491-503.

84 Meraviglia S, Lo Presti E, Tosolini M, et al. Distinctive features of tumor-infiltrating $\gamma \delta$ T lymphocytes in human colorectal cancer. Oncoimmunology 2017;6:e1347742

85 Wang J, Lin C, Li H, et al. Tumor-Infiltrating $\gamma \delta \mathrm{T}$ cells predict prognosis and adjuvant chemotherapeutic benefit in patients with gastric cancer. Oncoimmunology 2017:6:e1353858

86 Edin S, Kaprio T, Hagström J, et al. The Prognostic Importance of CD20+ B lymphocytes in Colorectal Cancer and the Relation to Other Immune Cell subsets. SC Rep 2019;9:19997.

87 Sautès-Fridman C, Lawand M, Giraldo NA, et al. Tertiary lymphoid structures in cancers: prognostic value, regulation, and manipulation for therapeutic intervention. Front Immunol 2016;7:407

88 Berntsson J, Eberhard J, Nodin B, et al. Expression of programmed cell death protein 1 (PD-1) and its ligand PD-L1 in colorectal cancer: relationship with sidedness and prognosis. Oncoimmunology 2018;7:e1465165.

89 Feng $\mathrm{D}, \mathrm{Qin} \mathrm{B}, \mathrm{Pal} \mathrm{K}$, et al. BRAF ${ }^{\mathrm{V} 600 \mathrm{E}}$-induced, tumor intrinsic $\mathrm{PD}-\mathrm{L} 1$ can regulate chemotherapy-induced apoptosis in human colon cancer cells and in tumor xenografts. Oncogene 2019;38:6752-66

90 Koganemaru S, Inoshita N, Miura Y, et al. Prognostic value of programmed death-ligand 1 expression in patients with stage III colorectal cancer. Cancer Sci 2017; 108:853-8

91 Dunne PD, McArt DG, O'Reilly PG, et al. Immune-Derived PD-L1 gene expression defines a subgroup of stage II/III colorectal cancer patients with favorable prognosis who may be Harmed by adjuvant chemotherapy. Cancer Immunol Res 2016;4:582-91.

92 Smyrk TC, Watson P, Kaul K, et al. Tumor-Infiltrating lymphocytes are a marker for microsatellite instability in colorectal carcinoma. Cancer 2001;91:2417-22.

93 Llosa NJ, Cruise M, Tam A et al. The vigorous immune microenvironment of microsatellite instable colon cancer is balanced by multiple counter-inhibitory checkpoints. Cancer Discov 2015:5:43-51.

94 Carethers JM, Chauhan DP, Fink D, et al. Mismatch repair proficiency and in vitro response to 5-fluorouracil. Gastroenterology 1999:117:123-31.

95 André T, de Gramont A, Vernerey D, et al. Adjuvant fluorouracil, leucovorin, and oxaliplatin in stage II to III colon cancer: updated 10-year survival and outcomes according to BRAF mutation and mismatch repair status of the MOSAIC study. J Clin Oncol 2015;33:4176-87 
96 Seligmann JF, FOxTROT Collaborative Group. FOxTROT: neoadjuvant FOLFOX chemotherapy with or without panitumumab (Pan) for patients (PTS) with locally advanced colon cancer (CC) [abstract]. J Clin Oncol 2020;38 (Supp 15):P4013

97 Cercek A, Dos Santos Fernandes G, Roxburgh CS, et al. Mismatch repair-deficient rectal cancer and resistance to neoadjuvant chemotherapy. Clin Cancer Res 2020;26:3271-9.

98 des Guetz G, Mariani P, Cucherousset J, et al. Microsatellite instability and sensitivitiy to FOLFOX treatment in metastatic colorectal cancer. Anticancer Res 2007;27:2715-9.

99 Magrini R, Bhonde MR, Hanski M-L, et al. Cellular effects of CPT-11 on colon carcinoma cells: dependence on p53 and hMLH1 status. Int J Cancer 2002;101:23-31.

100 Bras-Gonçalves RA, Rosty C, Laurent-Puig P, et al. Sensitivity to CPT-11 of xenografted human colorectal cancers as a function of microsatellite instability and p53 status. Br J Cancer 2000;82:913-23.

101 Fallik D, Borrini F, Boige V, et al. Microsatellite instability is a predictive factor of the tumor response to irinotecan in patients with advanced colorectal cancer. Cancer Res 2003;63:5738-44.

$102 \mathrm{Ma}$ J, Zhang Y, Shen $\mathrm{H}$, et al. Association between mismatch repair gene and irinotecan-based chemotherapy in metastatic colon cancer. Tumour Biol 2015;36:9599-609.

103 Bertagnolli MM, Niedzwiecki D, Compton CC, et al. Microsatellite instability predicts improved response to adjuvant therapy with irinotecan, fluorouracil, and leucovorin in stage III colon cancer: cancer and leukemia group B protocol 89803. J Clin Oncol 2009;27:1814-21.

104 Klingbiel D, Saridaki Z, Roth AD, et al. Prognosis of stage II and III colon cancer treated with adjuvant 5-fluorouracil or FOLFIRI in relation to microsatellite status: results of the PETACC-3 trial. Ann Oncol 2015:26:126-32.

105 Ambe K, Mori M, Enjoji M. S-100 protein-positive dendritic cells in colorectal adenocarcinomas. distribution and relation to the clinical prognosis. Cancer 1989;63:496-503

106 Nakayama Y, Inoue Y, Minagawa N, et al. Relationships between S-100 proteinpositive cells and clinicopathological factors in patients with colorectal cancer. Anticancer Res 2003;23:4423-6.

107 Gulubova MV, Ananiev JR, Vlaykova TI, et al. Role of dendritic cells in progression and clinical outcome of colon cancer. Int J Colorectal Dis 2012;27:159-69.

108 Nagorsen D, Voigt S, Berg E, et al. Tumor-infiltrating macrophages and dendritic cells in human colorectal cancer: relation to local regulatory T cells, systemic T-cell response against tumor-associated antigens and survival. J Trans/ Med 2007; 5:62.

109 Schwaab T, Weiss JE, Schned AR, et al. Dendritic cell infiltration in colon cancer. J Immunother 2001;24:130-7.

110 Sandel MH, Dadabayev AR, Menon AG, et al. Prognostic value of tumor-infiltrating dendritic cells in colorectal cancer: role of maturation status and intratumoral localization. Clin Cancer Res 2005;11:2576-82.

111 Obeid M, Tesniere A, Ghiringhelli F, et al. Calreticulin exposure dictates the immunogenicity of cancer cell death. Nat Med 2007:13:54-61.

112 Apetoh L, Ghiringhelli F, Tesniere A, et al. The interaction between HMGB1 and TLR4 dictates the outcome of anticancer chemotherapy and radiotherapy. Immunol Rev 2007;220:47-59.

113 Peng R-Q, Chen Y-B, Ding Y, et al. Expression of calreticulin is associated with infiltration of T-cells in stage IIIB colon cancer. World J Gastroenterol 2010;16:2428-34.

114 Meads MB, Gatenby RA, Dalton WS. Environment-mediated drug resistance: a major contributor to minimal residual disease. Nat Rev Cancer 2009;9:665-74.

115 Park JH, Richards CH, McMillan DC, et al. The relationship between tumour stroma percentage, the tumour microenvironment and survival in patients with primary operable colorectal cancer. Ann Oncol 2014;25:644-51.

116 Gonçalves-Ribeiro S, Díaz-Maroto NG, Berdiel-Acer M, et al. Carcinoma-Associated fibroblasts affect sensitivity to oxaliplatin and 5FU in colorectal cancer cells. Oncotarget 2016;7:59766-80.
117 Hu Y, Yan C, Mu L, et al. Fibroblast-Derived exosomes contribute to chemoresistance through priming cancer stem cells in colorectal cancer. PLoS One 2015; 10:e0125625.

118 Dienstmann R, Villacampa G, Sveen A, et al. Relative contribution of clinicopathological variables, genomic markers, transcriptomic subtyping and microenvironment features for outcome prediction in stage II/III colorectal cancer. Ann Oncol 2019;30:1622-9.

119 Tsujino T, Seshimo I, Yamamoto H, et al. Stromal myofibroblasts predict disease recurrence for colorectal cancer. Clin Cancer Res 2007;13:2082-90.

$120 \mathrm{Gu} \mathrm{J,} \mathrm{Li} \mathrm{Z,} \mathrm{Zhou} \mathrm{J,} \mathrm{et} \mathrm{al.} \mathrm{Response} \mathrm{prediction} \mathrm{to} \mathrm{oxaliplatin} \mathrm{plus} \mathrm{5-fluorouracil}$ chemotherapy in patients with colorectal cancer using a four-protein immunohistochemical model. Oncol Lett 2019:18:2091-101.

121 Xiong Y, Wang $\mathrm{K}$, Zhou $\mathrm{H}$, et al. Profiles of immune infiltration in colorectal cancer and their clinical significant: a gene expression-based study. Cancer Med 2018;7:4496-508.

122 Becht E, de Reyniès A, Giraldo NA, et al. Immune and stromal classification of colorectal cancer is associated with molecular subtypes and relevant for precision immunotherapy. Clin Cancer Res 2016;22:4057-66.

123 Allen WL, Dunne PD, McDade S, et al. Transcriptional subtyping and CD8 immunohistochemistry identifies patients with stage II and III colorectal cancer with poor prognosis who benefit from adjuvant chemotherapy. JCO Precis Oncol 2018:2:1-15.

124 Song N, Pogue-Geile KL, Gavin PG, et al. Clinical outcome from oxaliplatin treatment in stage II/III colon cancer according to intrinsic subtypes: secondary analysis of NSABP C-07/NRG oncology randomized clinical trial. JAMA Oncol 2016;2:1162-9.

125 Pogue-Geile KL, Andre T, Song N, et al. Association of colon cancer (CC) molecular signatures with prognosis and oxaliplatin prediction-benefit in the mosaic trial (multicenter International study of Oxaliplatin/5FU-LV in the adjuvant treatment of colon cancer) [abstract]. J Clin Oncol 2019;37 (Supp 15):P3503

126 Stintzing S, Wirapati P, Lenz H-J, et al. Consensus molecular subgroups (CMS) of colorectal cancer (CRC) and first-line efficacy of FOLFIRI plus cetuximab or bevacizumab in the FIRE3 (AIO KRK-0306) trial. Ann Oncol 2019:30:1796-803.

127 Lenz H-J, Ou F-S, Venook AP, et al. Impact of consensus molecular subtype on survival in patients with metastatic colorectal cancer: results from CALGB/SWOG 80405 (Alliance). J Clin Oncol 2019;37:1876-85.

128 Marisa L, Ayadi M, Balogoun R, et al. Clinical utility of colon cancer molecular subtypes: validation of two main colorectal molecular classifications on the PETACC-8 phase III trial cohort [abstract]. J Clin Oncol 2017;35 (Supp 15):P3509

129 Trinh A, Trumpi K, De Sousa E Melo F, et al. Practical and robust identification of molecular subtypes in colorectal cancer by immunohistochemistry. Clin Cancer Res 2017:23:387-98

130 Okita A, Takahashi S, Ouchi K, et al. Consensus molecular subtypes classification of colorectal cancer as a predictive factor for chemotherapeutic efficacy against metastatic colorectal cancer. Oncotarget 2018;9:18698-711.

131 Del Rio M, Mollevi C, Bibeau F, et al. Molecular subtypes of metastatic colorectal cancer are associated with patient response to irinotecan-based therapies. Eur J Cancer 2017:76:68-75.

132 Hof J, Kok K, Sijmons RH, et al. Systematic review of the prognostic role of the immune system after surgery of colorectal liver metastases. Front Oncol 2019;9:148.

133 Mlecnik B, Van den Eynde M, Bindea G. Comprehensive Intrametastatic immune quantification and major impact of immunoscore on survival. J Natl Cancer Inst 2018;110:97-108 doi:10.1093/jnci/djx123.

134 Halama N, Michel S, Kloor M, et al. Localization and density of immune cells in the invasive margin of human colorectal cancer liver metastases are prognostic for response to chemotherapy. Cancer Res 2011;71:5670-7.

135 Shahda S, Noonan AM, Bekaii-Saab TS, et al. A phase II study of pembrolizumab in combination with mFOLFOX6 for patients with advanced colorectal cancer [abstract]. J Clin Oncol 2017;35:P3541

136 Pfirschke C, Engblom C, Rickelt S, et al. Immunogenic chemotherapy sensitizes tumors to checkpoint blockade therapy. Immunity 2016;44:343-54. 